\title{
ÖĞRENİLMIŞ ANLAMSIZLIK ÖLÇEĞİ: GEÇERLİK VE GÜVENİRLİK ÇALIŞMASI
}

\author{
LEARNED MEANINGLESSNESS SCALE: A STUDY OF VALIDITY AND \\ RELIABILITY
}

\author{
Melek KALKAN ${ }^{1}$ - Meryem VURAL BATIK ${ }^{2}$
}

\section{$\ddot{O} \mathbf{z}$}

$\mathrm{Bu}$ araştırma Öğrenilmiş Anlamsızlık Ölçeği'ni (ÖAÖ) geliştirmek ve psikometrik özelliklerini incelemek amacıyla yapılmıştır. Araştırma ya \%64,7'si kadın ve \%35,2'si erkek olmak üzere toplam 815 üniversite öğrencisi katılmıştır. Ölçek geliştirilirken beş çalışma grubu oluşturulmuştur. Birinci çalışma grubunu madde havuzu oluşturmak amacıyla ulaşılan 150 öğrenci; ikinci çalışma grubunu madde-toplam test korela syonlarını belirlemek amacıyla ulaşılan 53 öğrenci; üçüncü çalışma grubunu ölçeğin yapı geçerliğini test etmek amacıyla ulaşılan 333 öğrenci; dördüncü çalışma grubunu oluşturulan modelin uyum değerlerini sınamak amacıyla ulaşılan 238 öğrenci; beşinci çalışma grubunu ise ölçeğin test-tekrar test güvenirliğini ölçmek amacıyla ulaşılan 41 öğrenci oluşturmaktadır. Öğrenilmiş Anlamsızlık Ölçeği, 23 maddeden oluşan beşli Likert tipi bir ölçektir. Ölçeğin yap1 geçerliği sınamak için Açımlayıcı Faktör Analizi yapılmış ve ölçeğin iki faktörden oluştuğu belirlenmiştir. Bu iki faktör toplam varyansın \%54,21'iniaçıkla maktadır. Bu faktörler "Anlamsızlık" ve "Anla m Arayışı" olarak isimlendirilmiştir. Doğrulayıcı Faktör Analizi sonucunda ise ölçeğe ilişkin iki faktörlü modelin iyi uyum gösterdiği belirlenmiştir. Ölçeğin güvenirliğini test etmek amacıyla hesaplanan Cronbach alfa iç tutarlık katsayısı .94, test yarılama güvenirliği katsayısı ilk yarı için .89, ikinci yarı için .89, test-tekrar test korelasyon katsayısı ise .93 'tür. Bu sonuçlar, geliştirilen Öğrenilmiş Anlamsızlık Ölçeği’nin geçerli ve güvenilir olduğunu göstermektedir.

Anahtar kelimeler: Anlamsızlık, anlam arayışı, ölçek, geçerlik, güvenirlik.

\begin{abstract}
This study is carried out in order to develop the Learned Meaninglessness Scale (LMS) and examine its psychometric properties. 815 university students in total, 64,78\% female and $35,2 \%$ male, participated in this study. Five study groups are formed during the development of the scale. The first study group consist s of 150 students in order to form the item pool; the second study group consists of 53 students that are reached to determine item-total test correlations; the third study group consists of 333 students that are reached to test the construct validity of the scale; the fourth study group consists of 238 students that are reached to test the adaptive values of the model formed; the fifth study group consists of 41 students that are reached to measure test - retest reliability of the scale. The LMS is five point Likert scale consisting of 23 items. Exploratory factor analysis is made in order to test the construct validity of the scale and the scale is found to consist of two factors. These two factors explain 54,21\% of the total variance. These factors are called "Meaninglessness" and "Search for Meaning". In consequence of Confirmatory Factor Analysis, the two-factor model related to the scale adjusts well. Cronbach's alfa internal consistency coefficient that is calculated to test the reliability of the scale is .94, split-half reliability coefficient is .89 for the first half, .89 for the second half, test-retest correlation coefficient is 93. These results show that the Learned Meaninglessness Scale that is developed is valid and reliable.
\end{abstract}

Keywords: Meaninglessness, search for meaning, scale, validity, reliability.

\footnotetext{
1 Ondokuz Mayıs Üniversitesi, mkalkan@omu.edu.tr, Orcid: 0000-0002-1280-5952

2 Ondokuz Mayıs Üniversitesi, meryem.vural@omu.edu.tr, Orcid: 0000-0002-7836-7289
} 


\section{GíRiș}

İnsan bir taraftan yaşamdaki amacını anlamlı kılacak bir varoluş belirlemeye çalışırken, diğer taraftan varoluşunun anlamsızlığını giderecek inanışlara sığınır. Hem din, hem de felsefe ve psikolojideki öğreti ve inanışlar insanın yaşamını anlamlandırmada kolaylık sağlar. Felsefe, bireylerin "yaşamının anlamını" temel alırken; psikoloji "anlamlı yaşamak" üzerinde çalışmalarını yoğunlaştırmaktadır.

Maslow (1970) insanın temel ihtiyaçlarından söz ederken kendini gerçekleştirmenin bilme ve anlama ihtiyacına karşılık geldiğini belirtmekte, kişinin yaşamını anlaması ve yaşama anlam katmasının öneminden söz etmektedir (Maslow, 1970). Buna karşılık Adler (2000) "yaşamın anlamı nedir" sorusu üzerinde pek çok insanın düşünmediği ve çözüm üretmediğini, ancak insanların bir yenilgiye uğradıkları durumda bu soruya yöneldiklerini söylemektedir. Şüphesiz "insanın anlam arayışı içsel denge yerine içsel gerilim yaratabilir. Ruh sağlığının vazgeçilmez ön koşulu da işte bu gerilimdir" (Frankl, 1998). Ruh sağlığı açısından insanın ihtiyaç duyduğu şey "gerilimsizlik" değil, uğruna çaba göstermeye değer bir amaç için mücadele etmektir (Frankl, 1998). Özgecilik, kendini bir nedene adamak, yaratıcılık, hedonistik çözüm, kendini gerçekleştirme ve kendini aşma bireylerin yaşamlarında anlam arayışlarına dayanak oluşturmaktadır (Yalom, 2001). Yalom (2002)'a göre insanın yaşamdaki en önemli görevlerinden biri yaşamı destekleyecek anlam yaratmaktır. Bunu ihmal etmek, kaçınmak veya daha kolay baş edilebilir bir duruma dönüştürmek işe yaramayacaktır.

Yaşamın anlamıyla ilgili yapılan çalışmalar yaşamda anlam eksikliğinin patoloji ve olumsuz yaşam olaylarıyla ilişkili olduğunu, diğer taraftan yaşama ilişkin anlamın olumlu ruh hali ve iyilik durumu ile ilişkisini göstermektedir. Gerçek benlikle ilgili özelliklerin yaşamda gelişmiş bir anlama yol açtığ (Schlegel, Hicks, Arndt, ve King, 2009), yaşamda özel anlama sahip olmanın iç huzur ve psikolojik iyi oluşa katkı sağladığı (Fry, 2000), yaşama ilişkin daha az anlam bulan bireylerin daha fazla depresif belirtiler gösterdikleri (Simonelli, Fowler, Maxwell ve Andersen, 2008), yaşamdaki anlamın alkolizmle ilişkili olduğu (Kleftaras ve Katsogianni, 2012), temel kişilik eğilimlerinin anlam arayışını etkilediği (Steger, Kashdan, Sullivan ve Lorentz, 2008) görülmektedir. Anlamın güçlenmesi, kişinin sağlıklı kalabilmesini kolaylaştırmaktadır (Barnes, 2005).

Dolayısıyla her bireyin yaşamın anlamına ilişkin görüşü birbirinden farklıdır (Adler, 2000). Bu anlam, sadece kişinin kendisi tarafından bulunabilir olması nedeniyle eşsiz ve özeldir. Hatta bu anlam günden güne, saatten saate farklılık gösterir. Bu bağlamda yaşamın genel anlamı değil, belli bir anda yaşamın özel anlamı daha önemlidir (Frankl, 1998). Logoterapi, kişinin sorumluluklarının farkına varmasını sağlayarak, yaşamının potansiyel anlamını gerçekleştirmesine yardımcı olmaktadır. İnsanın temel motivasyonunun anlam arayışı olması, kaçınılmaz acı içinde bile anlamın var olması, yaşamın anlamını bulma konusunda insanların özgür olduğu düşüncesi, kişinin kendi yaşamının kontrolünü ve sorumluluğunu alması logoterapinin temel ilkelerini oluşturmaktadır (Barnes, 2005; Xu, 2010).

İnsan, yaşamın olumsuz yönlerini olumlu veya yapıcı şeylere yaratıcı bir yoldan dönüştürme yetisine sahiptir. Kişi umutsuz bir durumla karşlaştığında ve kaderine ilişkin tutumunu farklılaştırmayı başardığ 1 durumda, acıda bile anlam bulabilir ve acı olmaktan çıkar. Mutlu olmaya dönük bir neden oluştuktan sonra mutluluk gelir (Frankl, 1998). Yaşanılan olumsuz olaylar karşısında acı çekmek veya mutlu olmak kişinin tutumları tarafından belirlenir. Yaşamdaki olaylara ilişkin anlamı keşfetmeye çalışan bireyler, yaşamdaki varoluşlarının anlamını da bulabilirler. Yaşamda değiştirilmeyecek koşullar $d$ ahi olsa koşulları değiştirmeye çalışmak ve koşullara rağmen huzurunu korumak bir tercihtir. Bu 
açıklamalar George A. Sargent (1981)'in “öğrenilmiş anlamsızlık” kavramını akla getirmektedir.

Sargent (1981) “öğrenilmiş anlamsızlık”tan bahsettiği makalesinde kendisine "George, dünyanın bir şaka olduğunu anlamalısın. Adalet yoktur ve her şey tesadüfidir. Bunu anladığın zaman kendini ciddiye almanın ne kadar saçma olduğunu fark edeceksin" diyen bir terapistten ve ona yaptığg eleştiriden bahsetmekted ir (Sargent, 1981, s. 117).

Aklımda onun yanlışlığıyla ilgili hiçbir şüphe yok. Onu ne kadar yanlış olduğu konusunda hemen ikna etmeye çalıştım. İyi bir terapistti ve dünyadaki davranışlarına ve tepkilerine bakıldığında ne kadar anlamlı olduğunu çok net bir şekilde anlıyormuşçasına yaşamını sürdürdü. Başkalarını derinden korudu ve hastalarına ilişkin büyük sorumluluk aldı. Umarım terapisti (veya hastaları) anlamsızlığın bu denli anlam değiştirmesini fark etmesine ve düzeltmesine yardımcı oldu. Sanki amaç ve anlam duygusu kendi için bilinçsizdi ya da en azından mevcut farkındalığının dışındaydı (Sargent, 1981, s. 118).

Sargent'in "öğrenilmiş anlamsızlık" kavramı, yaşamda gelişen olaylara ve durumlara öznel anlamlar yüklemeyi ve herkes için ortak kabul gören bir anlam tanımı olmamasını açığa çıkarmaktadır. Yaşamın zorluklarına ve belirsizliklerine rağmen dayanıklı olmayı ve vazgeçmemeyi içermektedir. Frankl (1998) toplama kamplarından kurtulan ve hayatta kalabilen insanların ortak özelliğinin daha güçlü olmaları değil, daha dayanıklı ve mücadeleci olmalarını söylemektedir. Her türlü şarta rağmen yaşamda anlam bulabilmek ve yaşama tutunabilmektir. Nietzsche'nin "bizi öldürmeyen, güçlendirir" sözünde olduğu gibi yaşamın zorluklarında bir anlam bulmak yerine, bu zorlukları değişmez görüp anlamsızlığın içine düşen insanlar, zorlukları ve şartları değiştiremeyeceklerine inanıp yaşamdan vazgeçerler. Oysa yaşamdaki her şeyin bir anlamı olduğunu düşünüp, "anlamsız" olarak görülenlerin yaşamın anlamını keşfetmeye dönük bir araç olduğunu bilmek üzerine odaklanan bu zihinsel süreçte, yaşamın her koşulda yaşamaya değer olduğuna inanılır. Öğrenilmiş anlamsızlık bu noktada "yaşamın anlamı”na vurgu yapan çalışmalardan ayrılmaktadır.

$\mathrm{Bu}$ bağlamda bakıldığında yaşamın anlamına ilişkin yapılan psikolojik danışma veya psikoterapi, bireylerin edinmiş oldukları duygu ve düşüncelerini biçimlendirmelerine, keşfetmelerine ve sorumluluklarını almalarına yardımcı olacaktır. Çeşitli yönleriyle anlam düzeylerini ölçmeye yönelik Türkiye'de geliştirilmiş ve uyarlanmış bazı ölçme araçları (Akın ve Taş, 2015; Demirdağ ve Kalafat, 2015; Güven, 2015) bulunmakla birlikte, doğrudan anlamsızlığa odaklanan ve özellikle de öğrenilmiş anlamsızlığı değerlendirmeyi amaçlayan bir ölçme aracına rastlanmamıştır. $\mathrm{Bu}$ amaçla bu çalışmada Sargent'in "öğrenilmiş anlamsızlık" kavramı temel alınarak bir ölçme aracı geliştirilmiş ve geçerlik-güvenirlik düzeyi belirlenmiştir. $\mathrm{Bu}$ ölçme aracının psikolojik yardım sürecinde varoluşsal ve yaşamın anlamına ilişkin sorunlar yaşayan danışanlarda yararlı olacağı düşünülmektedir.

\section{YÖNTEM}

\section{1. Çalışma grubu}

Bu çalışma bir devlet üniversitesinde öğrenim gören ve seçkisiz örnekleme yöntemiyle belirlenen $528 \mathrm{kad}$ ın $(\% 64,78)$ ve $287(\% 35,2)$ erkek öğrenci ile gerçekleştirilmiştir $(\mathrm{N}=815)$. Kat1lımcıların \%18,3'ü birinci sinıf (n=149), \%24,4'ü ikinci sınıf (n=199), \%26,9'u üçüncü sinıf $(n=219)$ ve \%30,4'ü dördüncü sınıf $(n=248)$ öğrencisidir. Araştırmaya katılan üniversite öğrencilerinin yaş ortalaması ise $21.57(\mathrm{Ss}=2.78)$ 'dir. 
Öğrenilmiş Anlamsızlık Ölçeği’nin geliştirilmesi sürecinde beş çalışma grubu oluşturulmuştur: Birinci çalışma grubunu, madde havuzu için ulaşılan \%50'si kadın $(\mathrm{n}=75)$ ve \%50'si erkek (n=75) olmak üzere 150 öğrenci oluşturmaktadır. İkinci çalışma grubu, madde havuzundaki ifadelerin anlaşılırlığını ve madde-test korelasyonlarını belirlemek için ulaşılan $\% 58,51$ 'i kadın $(n=31)$ ve \%41,5'i erkek $(n=22)$ olmak üzere 53 öğrenciden oluşmaktadır. Üçüncü çalışma grubu, ölçeğin yapı geçerliğini belirlemek için yapılan Açımlayıcı Faktör Analizi (AFA) gerçekleştirilen \%64,6'sı kadın $(n=215)$ ve \%35,4'ü erkek $(n=118)$ olmak üzere 333 öğrenciden oluşmaktadır. Dördüncü çalışma grubu, oluşturulan modelin uyum değerlerini sınamak amacıyla Doğrulayıcı Faktör Analizi (DFA) için ulaşılan \%73,1'i kadın $(n=174)$ ve $\% 26,9$ 'u erkek $(n=64)$ olmak üzere 238 öğrenciden oluşmaktadır. Beşinci çalışma grubunda ise ölçeğin test- tekrar test güvenirliğini ölçmek amacıyla ulaşılan 33'ü kız ve 8'i erkek olmak üzere 41 üniversite öğrencisi bulunmaktadır.

\section{2. İşlem Yolu}

Öğrenilmiş Anlamsızlık Ölçeği’nin geliştirilme sürecinin ilk aşamasında, ölçülmek istenen "öğrenilmiş anlamsızlık" ile ilgili kapsamlı bir literatür taraması yapılmış ve bir tanım oluşturulmuştur. Bu tanım doğrultusunda öğrenilmiş anlamsızlığı ölçtüğü düşünülen 5 örnek ifade yazılmış ve madde havuzu oluşturmak amaciyla üniversite öğrencilerine $(n=150)$ başvurulmuştur. Ardından toplanan maddeler incelenmiş, oluşturulan "öğrenilmiş anlamsızlık" tanımının sınırlılıkları içinde bu tanımı tüm özellikleri ile kapsayacağı düşünülen 49 ifadeden oluşan bir madde havuzu hazırlanmıştır. Oluşturulan madde havuzundaki ifadeler, uzmanlık alanı Psikolojik Danışma ve Rehberlik olan beş öğretim üyesinin görüşüne sunulmuştur. Konu, kapsam ve dil kullanımı açısından uzmanlardan alınan geribildirimler doğrultusunda bazı ifadeler çıkartılırken, bazıları tekrar düzeltilmiş ve toplam 37 maddeden oluşan deneme formu hazırlanmıştır. Deneme formunda yer alan her bir ifadenin karşısına beş seçenek (1- Hiç katılmıyorum, 2- Kısmen katılıyorum, 3- Orta düzeyde katılıyorum, 4Çoğunlukla katılıyorum, 5- Tamamen katılıyorum) yerleştirilerek beşli Likert tipi bir deneme ölçeği oluşturulmuştur.

İkinci aşamada pilot uygulama 53 öğrenci ile gerçekleştirilmiş, madde-toplam test korelasyon değerleri ve iç tutarlık katsayısı hesaplanmıştır. Madde-toplam test korelasyon değerleri .30'un altında olan 3 madde çıkartılmış ve 34 maddeden oluşan deneme ölçeği oluşturulmuştur.

Üçüncü aşamada 34 maddelik deneme ölçeği 333 üniversite öğrencisine uygulanmış ve madde-toplam test korelasyon katsayısı tekrar hesaplanmıştır. Madde-toplam test korelasyon değeri .30'un altında olan 1 madde çıkartılarak 33 madde ile AFA yapılmıştır. Faktör analizi bulgularına göre de 10 madde çıkartılmış ve 23 maddelik ölçek elde edilmiştir.

Dördüncü aşamada 23 maddelik ölçek 238 öğrenciye uygulanmış ve DFA yapılarak, oluşturulan modelin uyum değerleri hesaplanmıştır.

Son aşamada ise 23 maddelik son ölçek formu 41 öğrenciye bir ay arayla uygulanmış, ölçeğin test-tekrar test güvenirlik katsayısı hesaplanmıştır.

\subsection{Verilerin Toplanması ve Analizi}

Veriler, bir devlet üniversitesinde öğrenim görmekte olan üniversite öğrencilerinden gönüllülükleri doğrultusunda ders saati içerisinde toplanmıştır. Ölçek uygulaması yaklaşık 10 dakika sürmüştür. Verilerin analizinde SPSS 21 ve AMOS 22 programları kullanılmıştır. 


\section{BULGULAR}

\subsection{Pilot uygulama}

Pilot uygulama bir devlet üniversitesinde öğrenim gören 53 öğrenci üzerinde yapılmıştır. 37 maddeden oluşan deneme ölçeğinde yer alan maddelerin toplam test puanlarıyla korelasyonları hesaplanmıştır. Madde-toplam test korelasyon değerleri .30'un altında olan 3 madde çıkartılmıştır. 34 maddeden oluşan deneme ölçeğinin iç tutarlık katsayısı $\alpha=.95$ bulunmuştur.

\subsection{Madde-Toplam Test Korelasyon Analizi}

34 maddeden oluşan deneme ölçeği 333 üniversite öğrencisine uygulanmış ve maddetoplam test korelasyonları hesaplanmıştır. Madde-toplam test korelasyon değerleri .30'un altında olan 1 madde çıkartılmış ve deneme ölçeğinde 33 madde kalmıştır. Deneme ölçeğind eki 33 maddenin madde-toplam test korelasyonları Tablo 1'de verilmiştir.

Tablo 1. Madde-toplam test korelasyonları

\begin{tabular}{|c|c|}
\hline Madde no & Madde-toplam korelasyonu \\
\hline 1 & .581 \\
\hline 2 & .588 \\
\hline 3 & .606 \\
\hline 4 & .516 \\
\hline 5 & .631 \\
\hline 6 & .717 \\
\hline 7 & .664 \\
\hline 8 & .744 \\
\hline 9 & .425 \\
\hline 10 & 666 \\
\hline 11 & .432 \\
\hline 12 & .633 \\
\hline 13 & .541 \\
\hline 14 & .657 \\
\hline 15 & .726 \\
\hline 16 & .541 \\
\hline 17 & .681 \\
\hline 18 & .707 \\
\hline 19 & 606 \\
\hline 20 & .666 \\
\hline 21 & .566 \\
\hline 22 & .666 \\
\hline 23 & .566 \\
\hline
\end{tabular}




\subsection{Açımlayıcı Faktör Analizi (AFA)}

Yapı geçerliğini belirlemek için 333 üniversite öğrencisinden veri toplanmış, toplanan verilerin faktör analizine uygunluğu belirlemek için Kaiser-Meyer-Olkin (KMO) katsayısı ve Barlett Sphericitiy testi yapılmıştır. KMO değerinin .60'dan yüksek olması ve Barlett testinin anlamlı olması, verilerin faktör analizine uygun olduğunu göstermektedir (Büyüköztürk, 2011). Bu çalışmada KMO örneklem uygunluk katsayısı 0.943, Barlett Sphericity testi $\chi 2$ değeri ise $6455.261(\mathrm{p}<.001)$ bulunmuştur. $\mathrm{Bu}$ sonuçlar verilerin faktör analizi yapmaya uygun olduğunu göstermektedir.

Deneme ölçeğinin faktör yapısını ve alt boyutlarını belirlemek için AFA yapılmış ve varimax dik döndürme tekniği uygulanmıştır. Buna göre alt boyutlardaki faktör yük değerleri arasındaki farkı .10'dan az olan 10 madde çıkartılmıştır. Geriye kalan 23 madde ile tekrar AFA yapılmış ve özdeğerler incelenmiştir. Bu doğrultuda birinci faktörün özdeğeri 12.983 ve ikinci faktörün özdeğeri 3.540 olarak hesaplanmıştır. Üçüncü ve dördüncü faktörlerin özdeğerlerinin ise sirasıyla 1.407 ve 1.171 olduğu görülmüştür. Şekil 1'de verilen yamaç grafiğinde, verilerin iki faktörlü yapıya daha uygun olduğu görülmektedir.

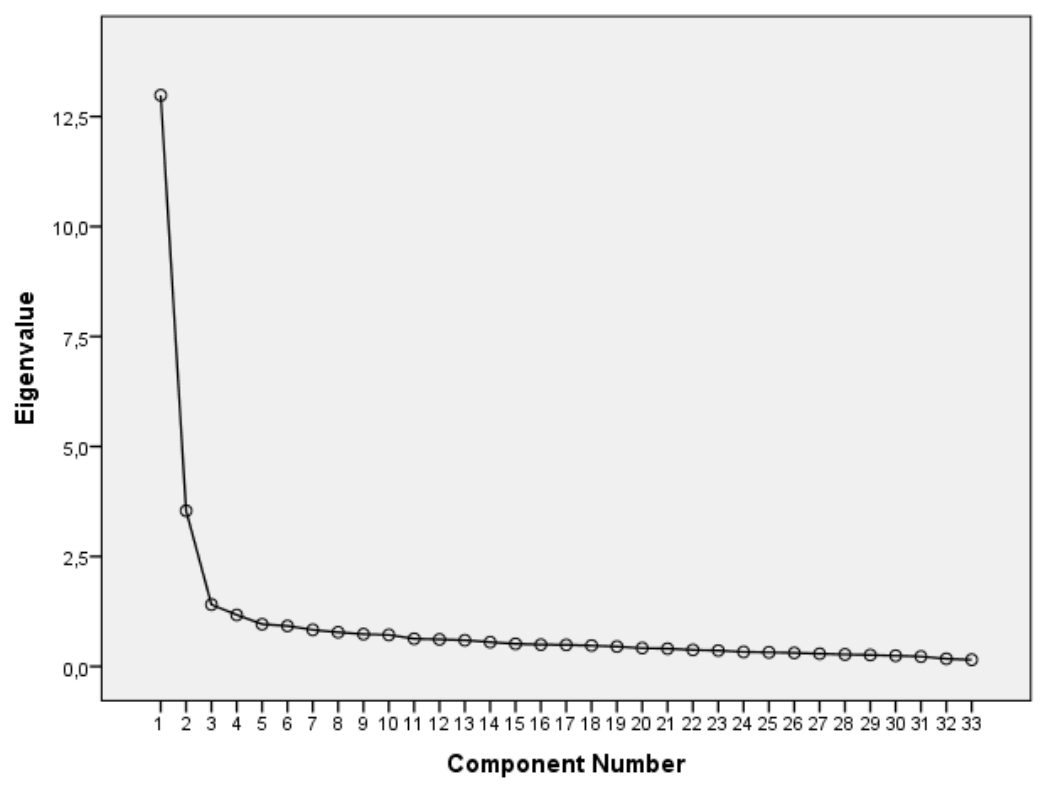

Şekil 1. Yamaç grafiği 
Özdeğerler ve yamaç grafiği dikkate alınarak iki faktörlü yapı oluşturulmuştur. Bu iki faktör toplam varyansın \%54,21'ini açıklamaktadır. Birinci faktöre ait özdeğer 9.692 olarak hesaplanmıştır ve bu faktör öğrenilmiş anlamsızlık değişkenine ait varyansın \%30,70'ini açıklamaktadır. İkinci faktöre ait özdeğer 2.778 olarak hesaplanmıştır ve bu faktör öğrenilmiş anlamsızlık değişkenine ait varyansın \%23,51'ini açıklamaktadır. Madde faktör yük değerleri .594 ile .801 arasında değişmektedir (Bkz. Tablo 2).

Tablo 2. Madde Faktör Yük Değerleri

\begin{tabular}{|c|c|c|}
\hline Madde no & 1.Faktör & 2.Faktör \\
\hline 1 & .649 & \\
\hline 3 & .671 & \\
\hline 4 & .762 & \\
\hline 5 & .754 & \\
\hline 6 & .727 & \\
\hline 7 & .670 & \\
\hline 8 & .639 & \\
\hline 9 & .625 & \\
\hline 10 & .706 & \\
\hline 12 & .666 & \\
\hline 15 & .655 & \\
\hline 17 & .686 & \\
\hline 22 & .755 & \\
\hline 23 & .661 & \\
\hline 2 & & .633 \\
\hline 11 & & .728 \\
\hline 13 & & 699 \\
\hline 14 & & .677 \\
\hline 16 & & .594 \\
\hline 18 & & .789 \\
\hline 19 & & .778 \\
\hline 20 & & .783 \\
\hline 21 & & .801 \\
\hline Özdeğer & 9.692 & 2.778 \\
\hline Varyans & $\% 30,70$ & $\% 23,51$ \\
\hline
\end{tabular}




\subsection{Doğrulayıcı Faktör Analizi (DFA)}

AFA sonucuna göre oluşturulan modeli test etmek için 23 maddelik ölçek 238 öğrenciye uygulanmış ve DFA yapılmıştır. Verinin oluşturulan modele uygunluğunun değerlendirilmesinde yaygın olarak kullanılan uyum iyiliği indeksleri; $\chi^{2}$, RMSEA, GFI, AGFI, NFI ve CFI'dır (Sümer, 2000). Uyum ölçütlerinin kabul edilebilir sınır değerleri (Byrne, 2009; Kline, 2005; Tabachnick ve Fidell, 2013) ve bu araştırmada önerilen modelin uyumuna ilişkin ölçüm sonuçları Tablo 3 ’te görülmektedir.

Tablo 3. Uyum İyiliği Ölçütleri ve Modele Ait Değerler

\begin{tabular}{cccc}
\hline Uyum Ölçütleri & $\begin{array}{c}\text { İyi Uyum Değer } \\
\text { Aralıkları }\end{array}$ & $\begin{array}{c}\text { Kabul Edilebilir Uyum } \\
\text { Değer Aralıkları }\end{array}$ & $\begin{array}{c}\text { Bu Modele Ait } \\
\text { Değer }\end{array}$ \\
\hline$\chi^{2} / \mathrm{sd}$ & $\chi^{2} / \mathrm{sd} \leq 3$ & $3<\chi^{2} / \mathrm{sd} \leq 5$ & 1.16 \\
$\mathrm{p}$ & $.05 \leq \mathrm{p} \leq 1$ & $.00 \leq \mathrm{p}<.05$ & .50 \\
$\mathrm{RMSEA}$ & $\mathrm{RMSEA}<.05$ & $.05 \leq \mathrm{RMSEA} \leq .10$ & .02 \\
$\mathrm{GFI}$ & $.95 \leq \mathrm{GFI} \leq 1$ & $.90 \leq \mathrm{GFI}<.95$ & .92 \\
$\mathrm{AGFI}$ & $.90 \leq \mathrm{AGFI} \leq 1$ & $.85 \leq \mathrm{AGFI}<.90$ & .89 \\
$\mathrm{NFI}$ & $.95 \leq \mathrm{NFI} \leq 1$ & $.90 \leq \mathrm{NFI}<.95$ & .91 \\
$\mathrm{CFI}$ & $.97 \leq \mathrm{CFI} \leq 1$ & $.95 \leq \mathrm{CFI}<.97$ & .98 \\
\hline
\end{tabular}

Modelin istatistiksel uygunluğu $\chi^{2} /$ sd ile test edilmiş ve 3 'ten küçük olduğu $\left(\chi^{2} / \mathrm{sd}=1.16\right)$ bulunmuştur. Ayrıca $p$ değerinin .05 'ten büyük olması ( $\left.p=.05\right)$ modelin istatistiksel olarak anlamlı olduğunu göstermektedir. Tablo 3'te görüldüğü gibi modelin diğer uyum indeksi değerlerinin $\mathrm{RMSEA}=.02, \mathrm{GFI}=.92, \mathrm{AGFI}=.89, \mathrm{NFI}=.91$ ve $\mathrm{CFI}=.98$ olduğu belirlenmiştir. Uyum ölçüt sonuçları incelendiğinde modelin iyi uyum ve kabul edilebilir uyum sınırları içerisinde olduğu görülmektedir. DFA ile ölçeğe ilişkin iki faktörlü modelin doğrulandığı söylenebilir. Öğrenilmiş Anlamsızlık Ölçeği'ne ilişkin iki faktörlü model Şekil 2'de verilmiştir. 


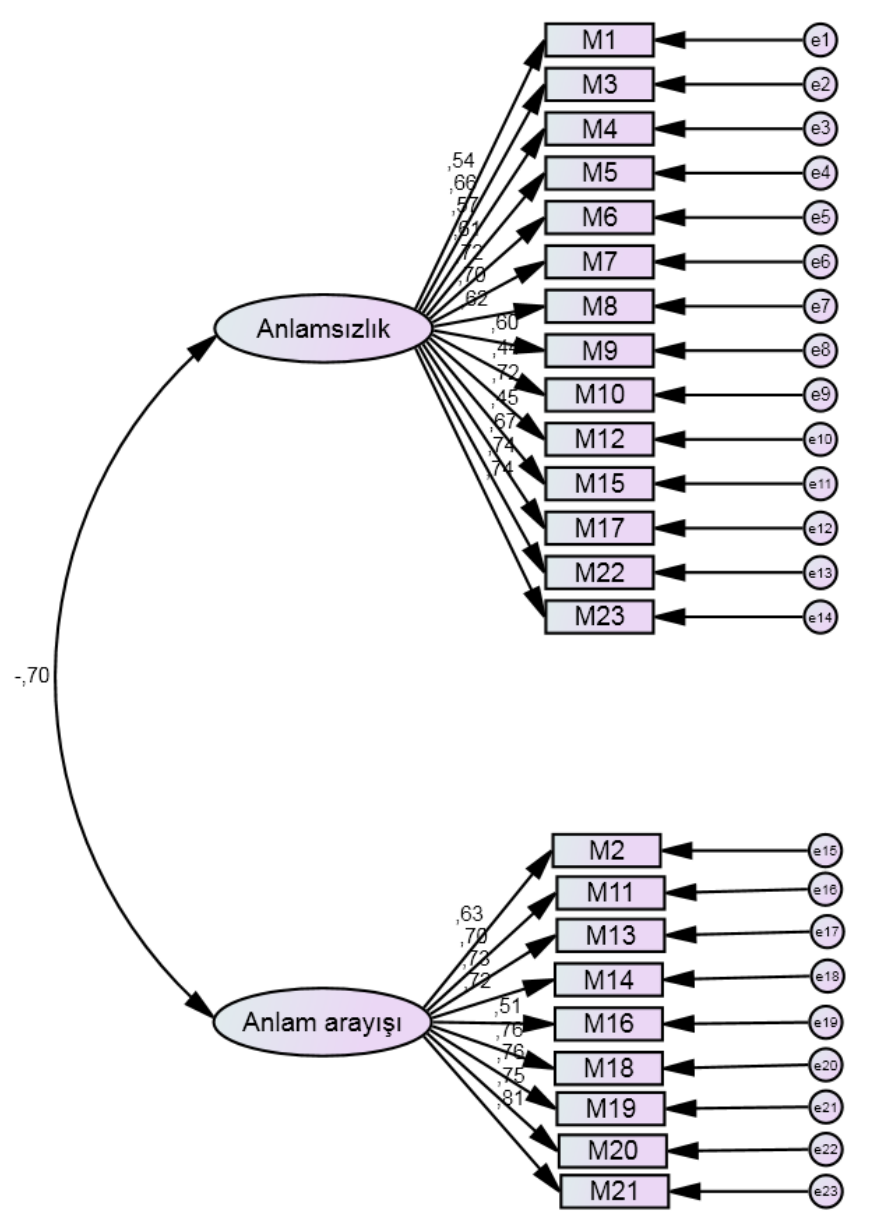

Şekil 2. Öğrenilmiş Anlamsızlık Ölçeği’ne İlişkin İki Faktörlü Model

Son olarak faktörlerde yer alan maddeler dikkate alınarak birinci faktör "Anlamsızlık" ve ikinci faktör "Anlam arayışı" olarak adlandırılmıştır. Birinci faktörde 14 madde ve ikinci faktörde 9 madde yer almaktadır. Alt boyut toplam puanları hesaplanırken ölçek puanları ters puanlanmamaktadır. Ölçekten toplam puan elde etmek için "Anlam arayışı" olarak adlandırılan ikinci faktörde yer alan maddeler ters puanlanmalıdır. Ölçekten alınabilecek en düşük puan 23 ve en yüksek puan ise 115'tir. Ölçekten yüksek puan alınması öğrenilmiş anlamsızlık düzeyinin yüksek olduğuna işaret etmektedir.

\section{5. Ölçeğin Güvenirliğine İlişkin Bulgular}

Ölçeğin güvenirliğini test etmek amacıyla Cronbach alfa iç tutarlık katsayısı, testi yarılama ve test-tekrar test güvenirlik katsayısı hesaplanmıştır. Bunun sonucunda elde edilen iç tutarlılık (Cronbach Alpha) katsayısı .94'tür. Test yarılama güvenirliği katsayısı ise, ilk yarı için .89 , ikinci yarı için .89 bulunmuştur. Ölçeğin test-tekrar test güvenirliği 41 öğrenciden bir ay arayla toplanan veriler arasındaki korelasyon katsayısı ile hesaplanmış ve .93 ( $\mathrm{p}<.000)$ bulunmuştur. Bu sonuçlar, Öğrenilmiş Anlamsızlık Ölçeği’nin güvenirliğinin yeterli düzeyde olduğunu göstermekted ir.

\section{TARTIŞMA VE SONUÇ}

$\mathrm{Bu}$ çalışmada bireylerin öğrenilmiş anlamsızlık düzeylerini belirlemeye yönelik bir ölçme aracı geliştirmek amaçlanmıştır. Frankl'a göre (1998) birey umutsuz bir durumla karşılaştığında ve kaderine ilişkin tutumunu değiștirmeyi başardığı durumda, acıda bile anlam bulabilir. Yaşamdaki olaylara ilişkin anlamı keşfetmeye çalışan bireyler, yaşamdaki 
varoluşlarının anlamını da bulabilirler. Öğrenilmiş anlamsızlık ise yaşamda gelişen olaylara ve durumlara öznel anlamlar oluşturmadan ve herkes için ortak kabul gören bir anlamı kabul etme ve yaşamın zorlukları karşısında vazgeçme olarak tanımlanabilir. $\mathrm{Bu}$ alandaki çalışmalara katkıda bulunmak amacıyla Sargent'in (1981) “öğrenilmiş anlamsızlık” kavramı temel alınarak bir ölçme aracı geliştirilmiştir.

Öğrenilmiş Anlamsızlık Ölçeği (ÖAÖ), 23 maddeden oluşan beşli Likert tipi bir ölçektir. ÖAÖ’nün yapı geçerliğini belirlemek amacıyla yapılan AFA sonuçları, varyansın \%54,21'ini açıklayan iki faktör olduğunu göstermiştir. Ölçeğe ilişkin iki faktörlü modelin uyumunu test etmek amacıyla yapılan DFA sonucunda, modele ilişkin uyum indeksi değerlerinin iyi uyum ve kabul edilebilir uyum sınırları içerisinde olduğu belirlenmiştir. Diğer bir deyişle AFA ile oluşturulan iki faktörlü modelin DFA ile doğrulandığı söylenebilir.

ÖAÖ’nün güvenirliği Cronbach alfa iç tutarlık katsayısı, testi yarılama ve test-tekrar test güvenirlik katsayısı ile hesaplanmıştır. Ölçeğin iç tutarlılık (Cronbach Alpha) katsayısı .94 , test yarılama güvenirliği katsayısı, ilk yarı için .89, ikinci yarı için .89 bulunmuştur. Ölçeğin test-tekrar test koralasyon katsayısı ise .93 ( $\mathrm{p}<.000)$ olarak hesaplanmıştır. Bu sonuçlar, ÖAÖ’nün güvenirliğinin yeterli düzeyde olduğunu göstermektedir.

Öğrenilmiş Anlamsızlık Ölçeği'nde “Anlamsızlık” olarak adlandırılan birinci faktörde 14 madde bulunmaktadır. Bu faktörde bulunan maddelere örnek olarak, "Yaşamda iyi şeyler yapmadı̆̆ım gibi, bundan sonra da iyi olacă̆ına inanmıyorum" ve "Ne kadar uğraşıp çaba göstersem de hiçbir zaman amaçlarımı gerçekleştiremeyeceğim" maddeleri verilebilir. "Anlam Arayışı" olarak adlandırılan ikinci faktörde ise 9 madde yer almaktadır. Bu faktörde "Tüm hatalarıma rağmen, bugün yaşamımı anlamlı kılacak şeyler bulmaya çalışırım" ve "Geçmiş deneyimlerimden yola çıkarak daha anlamlı şeyler yapmaya çalışırım" gibi ifadeler yer almaktadır. Alt boyut toplam puanları hesaplanırken ölçek puanları ters puanlanmamaktadır. Ölçekten toplam puan elde etmek için "Anlam arayışı" olarak adlandırılan ikinci faktörde yer alan maddeler ters puanlanmalıdır. Ölçekten alınabilecek en düşük puan 23 ve en yüksek puan ise $115^{\prime}$ tir. Ölçekten alınan toplam puanın yüksek olması öğrenilmiş anlamsızlık düzeyinin yüksek olduğuna işaret etmektedir.

Öğrenilmiş Anlamsızlı Ölçeği genç yetişkinlik döneminde olan üniversite öğrencileri üzerinde geliştirilmiştir. Gelecekte yapılacak çalışmalarda, ÖAÖ’nün geçerlik ve güvenirliğinin orta ve ileri yetişkinlik dönemlerinde olan bireyler üzerinde test edilmesi önerilebilir. Bu sınırlılık dikkate alınarak Öğrenilmiş Anlamsızlık Ölçeği’nin psikolojik danışma ve psikoterapilerde anlam arayışı içinde olan danışanları değerlendirmede kullanılabilecek yeterlikte psikometrik özelliklere sahip, geçerli ve güvenilir bir ölçek olduğu belirtilebilir.

\section{Kaynakça}

Adler, A. (2000). Yaşamın anlam ve amacı (Çev. K. Şipal), İstanbul: Say yayınları.

Akın, A., ve Taş, İ. (2015). Yaşamın anlamı ölçeği: geçerlik ve güvenirlik çalışması. Turkish Studies, 10, 3, 27-36.

Barnes, R. C. (2005). Logotherapy and the human spirit. Franklian psychology: An introduction to logotherapy. In G. E. Rice (Ed.), pp. 31-49. Texas: Viktor Frankl Institute of Logotherapy.

Büyüköztürk, Ş. (2011). Sosyal bilimler için veri analizi el kitabı: İstatistik, araştırma deseni, SPSS uygulamaları ve yorum. Ankara: Pegem Akademi Yayınları.

Byrne, B. M. (2009). Structural equation modeling with AMOS: Basic concepts, applications, and programming (2. bs.). New York: Routledge/Taylor \& Francis. 
Demirdağ, S. ve Kalafat, S. (2015). Yaşamın anlamı ölçeği: Türkçeye uyarlama, geçerlik ve güvenirlik çalışması. İn̈nü Üniversitesi Eğitim Fakültesi Dergisi, 16, 2, 83-95.

Frankl, V. (1998). İnsanın anlam arayışı. (Çev. S. Budak), Ankara: Öteki Psikoloji.

Fry, P. S. (2000). Religious involvement, spirituality and personal meaning for life: Existential predictors of psychological wellbeing in community residing and institutional care elders. Aging \& Mental Health, 4 (4), 375-387.

Güven, P. (2015). Üniversite öğrencilerinde yaşamın amacı ve anlamı ile yaşam doyumu ve yakın ilişkiler. Dokuz Eylül Üniversitesi, Eğitim Bilimleri Enstitüsü, Yüksek Lisans Tezi.

Kleftaras, G., \& Katsogianni, I. (2012). Spirituality, meaning in life, and depressive symptomatology in individuals with alcohol dependence. Journal of Spirituality in Mental Health, 14(4), 268-288.

Kline, R. B. (2005). Principles and practice of structural equation modeling (2nd Ed.). New York: Guilford

Maslow, A. H. (1970). Motivation and personality (2nd Ed.). New York: Harper \& Row.

Sargent, G. A. (1981). Transference and countertransference in logotherapy. The International Forum for Logotherapy, 5(2), 115-118.

Schlegel, R. J., Hicks, J. A., Arndt, J., \& King, L. A. (2009). Thine own self: True self concept accessibility and meaning in life. Journal of Personality and Social Psychology, 96 (2), 473-490.

Simonelli, L. E., Fowler, J., Maxwell, G. L., \& Andersen, B. L. (2008). Physical sequelae and depressive symptoms in gynecologic cancer survivors: meaning in life as a mediator. Annals of Behavioral Medicine, 35(3), 275-284.

Steger, M. F., Kashdan, T. B., Sullivan B. A., \& Lorentz, D. (2008). Understanding the search for meaning in life: Personality, cognitive style, and the dynamic between seeking and experiencing meaning. Journal of Personality, 76 (2), 199-228.

Sümer, N. (2000). Yapısal eşitlik modelleri: Temel kavramlar ve örnek uygulamalar. Türk Psikoloji Yazılarl, 3(6), 49-74.

Tabachnick, B. G., \& Fidell, L. S. (2013). Using multivariate statistics (2nd Ed.). Boston: Pearson.

$\mathrm{Xu}$, J. (2010). Logotherapy: A balm of gilead for aging? Journal of Religion, Spirituality \& Aging, 22(3), 180-195.

Yalom, I. D. (2001). Varoloşçu psikoterapi. Ankara: Kabalcı Yayınevi.

Yalom, I. D. (2002). Bă̆ışlanan terapi. İstanbul: Kabalcı Yayınevi.

Yılmaz, V., \& Çelik, H. E. (2009). Lisrel ile yapısal eşitlik modellemesi-I: Temel kavramlar, uygulamalar, programlama. Ankara: Pegem Akademi Yayınları. 